\title{
Marine spatial planning: risk or opportunity for fisheries in the North Sea?
}

\author{
Svein Jentoft and Maaike Knol
}

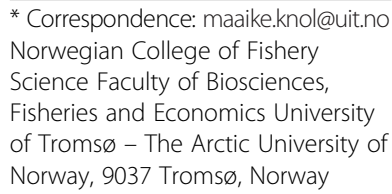

* Correspondence: maaike.knol@uit.no Norwegian College of Fishery Science Faculty of Biosciences, Fisheries and Economics University of Troms $\varnothing$ - The Arctic University of Norway, 9037 Tromsø, Norway

\begin{abstract}
The North Sea is one of the busiest marine areas in the world. It is also a major fisheries ground. Bordered by seven countries with their own spatial uses and claims, the stage is set for complex and demanding governance challenges. Recent decades have also seen user groups multiply, competition for space and resources increase, and the pressure on the marine environment and its living natural resources grow. As governments strive to balance conservation and economic development needs, they also have to deal with inter-as well as intra-national user conflicts. Marine Spatial Planning (MSP) has arrived as a new approach to these issues. It is argued that for North Sea fishing people and their communities MSP holds risks as well as opportunities, depending on which institutions are formed and what role they are allowed to play in the planning process.
\end{abstract}

Keywords: Marine spatial planning; Marine protected areas; Fisheries and coastal governance; Stakeholder conflict; Subsidiarity principle North Sea

\section{Introduction}

The North Sea is one of the most crowded marine areas in the world (Halpern et al. 2008; Jay 2012a). It is also a major fishing ground. Seven countries border the North Sea, each with their own spatial claims, cross-cutting ecosystem boundaries, an array of user groups, different governing systems, a shortage of cross-boundary mechanisms for settling disputes, and pressing demands for environmental protection. Fisheries, ocean and coastal governance are a daunting challenge beyond anyone's imagination.

It could still be argued that the North Sea is in many ways in a better situation than marine regions are in many other parts of the world. To begin with, North Sea countries share a common democratic culture, a factor that is not the case for all of Europe's regional seas. The North Sea countries also have a high score on the World Bank's "good governance index". Save for Norway, all of them are within the European Union (EU) and thus have an opportunity and the commitment to work together within common institutional frameworks, such as the OSPAR Convention, the Marine Strategy Framework Directive, Natura 2000 and the Common Fisheries Policy (CFP), to note but a few. If Marine Spatial Planning (MSP), which is the topic of this paper, needs cannot be realized and/or met under such cooperative frameworks, one would be hard-pressed to envision a situation in which it could.

From a MSP perspective, the situation in the North Sea nevertheless remains complex. Governments are not cooperating as well as they could; legislation is not as 
developed and synchronized as one could hope for (Drankier 2012); the interaction between different sectors and user-groups could be more constructive (Ritchie and Ellis 2010); and the status of the marine ecosystems and fisheries in the North Sea are hardly positive (ICES 2011). All of these aforementioned issues are problems that marine spatial planning MSP would need to relate to.

In this paper we argue that MSP cannot solely be thought of as a technical instrument. Rather, it should perceived as a multi-scalar and multi-sectoral governance mechanism (Kidd and Shaw 2013). MSP must also be about creating order and negotiating conflict between user-groups who do not always share the same goals, and whose powers, interests and worldviews differ sharply. MSP is therefore about much more than setting goals and implementing them.

To put MSP in a governance context where it belongs, we shall commence by defining what governance means, followed by a similar conceptual clarification of MSP. Coming from a fisheries research background we are particularly interested in what MSP represents as a challenge for this particular sector, which in the case of the North Sea has ancient roots. For that a micro-perspective is needed. The focus must also be on what MSP may mean to fishers and their local communities. Here, one should both have an eye for the risks as well as the opportunity which this new tool provides. From a fisheries sector and community perspective, attention must be paid to the competition for space and resources between fisheries and other stakeholders. Who are these stakeholders and what characterizes their spatial usage? Finally, the paper addresses some key governance principles as they apply to both fisheries governance and MSP in the North Sea, in particular those that relate to scale, subsidiarity, and participation in decision-making.

\section{Marine governance defined}

There is currently a huge and ever-growing body of literature on governance, in and of itself an indicator of a general interest in governing systems and mechanisms that are more inclusive and less state-centered than they used to be (Kjær 2004). Increasingly, societal governing is organized through partnership arrangements that involve industries and civil society. This is also occurring for many industries that operate in the North Sea (van Hoof and van Tatenhove 2009; van Leeuwen and van Tatenhove 2010). The move towards "governing as governance" (Kooiman 2003) is mostly perceived as a step in the direction of a more user-friendly, democratic, responsive, interactive and effective form of governing. Hence, such a move is associated with "good governance" as defined by the World Bank, the EU and others. Notably, governing as governance is partly an observation of what is actually going, as well as an instruction and norm-i.e. something that we should have more of. Not only does it promise a better working governing system, it also abides by some old governance principles that have intrinsic value.

Many definitions of marine governance in particular figure in the academic literature. In line with the general governance concept, a common denominator is the emphasis on the participatory approach involving market and civil society stakeholders. For instance, van Leeuwen and van Tatenhove (2010:591) define marine governance as, "the sharing of policy making competences in a system of negotiation between nested governmental institutions at several levels (international, supranational, national, 
regional and local) on the one hand, and state actors, market parties and civil society organizations on the other in order to govern activities at seas and their consequences." Below are two examples, one ancient and one modern, of such governance institutions for the marine environment that are relevant in a MSP and fisheries context.

\section{Polder model}

Despite its modern applications, the Polder model is not a recent invention. The particular historical context of this model in the Netherlands is rooted in the need to arrive at some consensus on how to tackle the constant challenge water presents. This has led to innovative thinking about how to govern. When the Polder model was initiated in the Middle Ages, communities had to put aside their differences and work together to maintain the dikes and pumping stations. Without this cooperation and shared responsibility, the polders would have flooded and everyone would have suffered.

Interestingly, the polder model still plays a role in Dutch politics. Glasbergen (2002), for example, talks about a "green polder model" as a tool for environmental governance. There are, however, mixed experiences with this model (Schreuder 2001; Woldendorp and Keman 2007), as is the case with most governance systems. Nevertheless, the fact that it is still relevant suggests that marine governance in the modern age is not so much about introducing entirely new and untested principles and governance mechanism, but rather about invoking solutions that have a deep-seated history.

\section{Regional advisory councils}

The set up and design of the regional advisory councils (RAC) as a form of "trans-national governance" (van Hoof and van Tatenhove 2009) of fisheries by the EU between 2002 and 2004, is largely structured as an interactive governance mechanism, based on similar principles as the Polder model, albeit on a much larger scale.

The first RAC to be established was for the North Sea (cf. Degnbol and Wilson 2008). Stakeholders of various sorts, be they the fishing industry, environmental organizations, consumer groups, women's networks or others, are represented. The RACs do not, however, have the same authority to make autonomous decisions as the Polder communities had. They are instead limited to providing advice to the Commission on fisheries regulatory matters. Broad participation is also meant to give legitimacy to the management process. Notably, the design and basic operating principles and experiences of the North Sea RAC (NSRAC) are relevant to MSP also because it has several sub-units, one of them devoted to MSP.

Not surprisingly, some of the seven RACs throughout Europe seem to work better than others. As for the NSRAC, according to Degnbol and Wilson (2008:193) "[it is] the relationship between the conservation non-governmental organizations (NGOs) and the industry that is the basic story about the NSRAC." According to these researchers, the latter tends to be the stronger partner-to the extent that the NGOs have been questioning their role and contribution. The frustration is not only directed at other stakeholder representatives as much as at the EU fisheries authorities. Fishing industry representatives often feel that their advice is not taken seriously into account and that they are therefore wasting time by participating (Ounanian et al. 2012). 
Rather than concluding decisively as to their potential, however, RACs could be seen as a lesson for MSP. Although the founding governance principles are relevant, one cannot expect organizations like the RACs to work well if the design does not match their mandate and if the external support is not there. That may well also become the fate of MSP. As the RAC experience demonstrate, to plan and govern overlapping activities in seas that are shared by several countries is demanding. Brussels is too far away to be able to feel the pulse of what is going on at local scales. Marine governance in the form of multi-scale MSP is about trying to reconcile conflicting demands. Although some distance may be needed in order to see the broader ecosystem picture, such reconciliation cannot easily be achieved from a distance.

\section{Marine spatial planning defined}

MSP is defined as "a process of analyzing and allocating parts of three-dimensional marine spaces to specific uses, to achieve ecological, economic, and social objectives that are usually specified through the political process" (Douvere and Ehler 2009:78) The idea of MSP is to foster rational use of a shared marine space that is scarce, and to secure the sustenance of fragile ecosystems. Additionally, MSP endeavors to create more conducive interactions among marine user groups in a way that balances the demands for economic development, human wellbeing and environmental conservation.

While some are more advanced than others, all of the countries that border the North Sea are now engaged in MSP in one way or other. Jay and colleagues (2012b) refer to MSP as "the new frontier." Although MSP holds great promise and widely adopted, it is hardly a panacea. It is a process that is socially, institutionally, and legally, and therefore also politically, intertwined, which sets the stage for political ambition that may cause conflict as interests and worldviews differ among the involved parties.

\section{Marine spatial planning as a wicked problem}

MSP is applied to social and ecological systems (SESs) that are inherently diverse, complex and dynamic, and work at multiple scales. Accordingly, MSP deals with problems that Rittel and Webber (1973) termed "wicked" (cf. also Jentoft and Chuenpagdee 2009). In such situations, one should not expect quick fixes; the problems are not expected to go away anytime soon. As wicked problems they are not solved once and for all but need constant attention, and it is hard to determine if and when they are solved, and for how long. They can at best be "tamed." Solutions are less than ideal and never given. Instead they are negotiated among stakeholders who tend to have different ideas about what the problem is. Decisions would therefore require compromise if agreement cannot be made.

In fact, the latter makes MSP a wicked problem in itself. As such it makes sense in theory, but is onerous in practice. As marine space gets more and more congested by the day, users find themselves in a situation where more space for one means less for others. Agreeing on how to allocate space among different user groups requires negotiation and cooperation. A complicating factor is that cross-border interaction in these spaces is unavoidable. For instance, fishing fleets are mobile and cannot easily be fenced in. While the fishing grounds may be stationary, the fishers themselves must move between varying areas depending on the fishing season and the species targeted. 
Likewise, oilrigs and marine aquaculture installations situated on fishing grounds or near shipping lanes may interfere with each other trigger conflict. This also frequently happens when marine protected areas (MPAs) interfere with fishing patterns.

\section{Nature conservation and marine protected areas}

As Jay and colleagues (2012c) observe, MSP has its origin in marine nature conservation and is a logical extension of marine protected areas (MPAs). The two share the ecosystem perspective and a holistic and integrated approach (Kidd et al. 2011). Experiences from the implementation of MPAs should therefore be useful to MSP.

In the EU, Natura 2000 creates a network of protected areas throughout Europe based on the criteria outlined in the EU Habitat and Bird Directives (see Fock 2011). In the case of the North Sea, nature conservation is integral to MSP. From a spatial perspective, it is not the number of MPAs per se that is of importance, but instead their size and regulatory content. In Germany, about 45 percent of the waters in the North Sea and the Baltic Seas are marine protected areas (MPA) under the Natura 2000 network $^{\mathrm{a}}$. This is impressive when compared to Scotland, where just 4 percent of the territorial waters are currently covered by Special Areas of Conservation (SAC) designation. There are no Special Protection Areas (SPAs) designated entirely in the Scottish marine environment ${ }^{\mathrm{b}}$. The Dogger Bank, shared by Germany, the Netherlands, the UK and Denmark is renowned as an important fishing area and nursing ground, but it is also the focal point of a new wind energy development program. Falling under the category "sandbanks slightly covered by seawater all the time", areas of the Dogger Bank are fit to fall under the Habitats Directive to become a Special Area of Conservation (Degnbol 2012).

MPAs (and MSP) are meant to be proactive mechanisms of area-based ecosystem management (Douvere and Ehler 2008). According to the precautionary principle lack of information is no excuse for inaction. All seven North Sea countries have ratified the Convention on Biological Diversity (CBD) and therefore this principle governs by implication. Yet, things are more difficult to implement in reality than they initially seem on the surface. MPAs cannot be easily imposed from the top down. Its development requires interactive processes at the regional scale. In Belgium this lesson was learned the hard way. As noted by Bogaert et al. (2009), the initial MPA designation process was top-down and received local resistance, and therefore failed. It had to be terminated, and could not be resumed before a more interactive process involving stakeholders was initiated six years later. This would also be a lesson. There is little reason to assume that MSP would be any different.

MPAs are most needed when numerous and cumulative activities expose risks to the environment. This is usually the situation near the coast and in limited ocean spaces such as the North Sea. It is not the same as when a MPA is established in the middle of the Atlantic where human presence is considerably limited. The rule seems to be that the easier their implementation due to minimal local resistance, the less is the need for them (Gilliland and Laffoley 2008). Marine ecosystems do not need MPAs if humans do not tamper with them, but that seems to be the case to a diminishing extent.

User-conflicts are likely to magnify and intensify as more and more MPAs are created. Uses for the same space are often incompatible and, if ways for different uses to co-exist cannot be found, it remains logical they must be kept apart. No wonder 
therefore that MPAs have received mixed support by fishers who find them as an intrusion into their freedom of access and movement (Jentoft et al. 2007). Fishers have their own precautionary principle in place (Degnbol and Wilson 2008). In the face of uncertainty, they do not easily put their livelihood or community at risk. That is also one reason why MPAs globally have received less support in the fishing population than many would have expected, and why they have been much slower in their implementation than originally anticipated (Chuenpagdee et al. 2013).

When fishers talk about MPAs and MSP, issues of exclusion are of primary concern. They are often told to fish somewhere else, while the recreational sector enjoys continued access. Such discrepancies in conservation policy need not be necessary, however. In fact, nature conservation instruments can allow multiple uses, including fishing under some form of regulation. Fishers are therefore not always opposed to nature conservation, and might find that it may actually work in their best interests. It is argued, thus, that nature conservation should be treated "as a means to achieve good environmental status of the ecosystem, based on its spatial, economic and conflict resolution dimensions" (Zacharoula et al. 2013).

Those affected are therefore better consulted or directly involved-as in the Polder model. The stakes are high for those who have much to lose. Fearing displacement, the fisher may invariably be skeptical, even when the plans for change promise a brighter future (Agardy et al. 2011). One tends to be less apprehensive when part of the process and has the opportunity to learn what is happening and why. Conversely, one is also inclined to be more positive when heard and respected.

\section{Fish and fisheries}

With more than 230 fish species, the North Sea is a rich fishing area. Norway, the UK, Denmark, Germany and The Netherlands each have a high presence in the North Sea fisheries, harvesting hundreds of thousands of tons every year, and in some instances with the consequence of severely reducing the biomass to a level where the International Council for the Exploration of the Sea (ICES) have advised against continued fishing. The North Sea cod was at an historical low in 2006. Despite quota regulation, by-catch and the discard resultant from mixed fisheries continues to be a problem. The same is the case with "ghost fishing", when gear are lost in the sea but continues to fish. The good news according to the Norwegian Institute of Marine Research in Bergen, however, is that herring shows a more positive development lately and the spawning stock is now in a better shape, well above the precautionary reference point. The same is true for the haddock, but less so with saith (ICES 2011).

The fishing industry is highly diversified with different kinds of users. As in all countries with a coastline, North Sea fishers make a living from harvesting marine resources using technology at various scales. In the UK, for instance, the commercial fishing fleet is largely made up of small boats. As of 2010, 78 percent of licensed vessels are smaller than 10 meters (cf. Cardwell 2012). In comparison, the Dutch fleet is of considerably larger scale ${ }^{c}$. In most instances, the smaller the vessels, the closer to shore they fish, the more simple technology they employ, and the smaller their ecological footprint. There is, however, an extensive large scale fishery on the North Sea, which is responsible for a major part of the total harvested volume of fish. Bottom trawls, typically 
employed by large scale fishing vessels, are harmful to the sea floor benthos, such as coral reefs and other marine life on the seabed. So-called beam trawls, a popular fishing method in Germany, Belgium and the Netherlands, have therefore been highly controversial, pitting biologists and ecologists up against the fishing industry (see van Ginkel 2009).

Fisheries have an ancient presence in the North Sea, and therefore a cultural heritage to maintain. In recent decades new marine industries have appeared, one of them aquaculture. Salmon raised in pens in the sea is now a major industry in Norway and the UK. For Scotland, for instance, (which today accounts for 90 percent of the UK production), the sky seems to be the limit. Scotland's National Marine Plan aims at an increase of finfish farmed at a rate of 4 percent per annum, which should lead to a 50 percent increase by 2020 (Scottish Government 2011). The expected rise of farmed shell fish, especially mussels, will likely experience a similar expansion. According to the most recent available statistics, the Netherlands is farming oyster mussels, eel, catfish and tilapia at over 4000 tons per year $^{\mathrm{d}}$. This is about one tenth of what Denmark produces ${ }^{\mathrm{e}}$.

\section{Other stakeholders and use(r)s of marine space}

Fishers find themselves in an increasingly congested area where space is getting increasingly scarce. This occurs both on land, on the coast and offshore due the expansion of existing usages as well as the introduction of new ones. As economic growth by exploiting marine resources, there is need to carefully plan for the management and conservation marine ecosystems. For fisheries this is no easy challenge, but they cannot anymore be looking inwards; they must also have an eye for what is happening in their environment, and consider who the other stakeholders are, what their particular stakes are, and how they operate.

\section{Oil industry}

In the 1950s, few believed that the North Sea contained a large petroleum potential. This changed when the Dutch Slochteren field was discovered, and the North Sea became what Yergin (1991) calls, one of the greatest investment projects in the world and a "technological marvel of the first order." Norway, the UK and the Netherlands are the major players in North Sea oil and gas, with the first topping in volume of oil produced. Apart from the potentially harmful environmental effects, oil and gas activities have direct spatial implications ${ }^{f}$. In addition to the large number of actual oilrigs, there are security zones around the platforms (500 meters around the platform where marine traffic such as fishing is banned) and thousands of kilometers of pipelines and cables over the sea bed, which in many instances have caused problems for trawl fishing.

\section{Shipping and military operations}

To the list of stakeholders in the North Sea we must add shipping and military operations. Every year, roughly 34,000 sea-going vessels call at the port of Rotterdam. Many of the North Sea countries, namely France, the UK, Belgium, and, leading them all, the Netherlands, have pronounced sand mining industries. With sea-levels rising, sand 
mining will likely increase considerably. Estimates for the Netherlands suggest that sand mining will soon reach approximately 85 million cubic meters per year ${ }^{\mathrm{h}}$.

\section{Coastal communities and recreation}

As noted in the Dutch Water Management Plan, the coast is an attractive place to live, work and to enjoy leisure time ${ }^{\mathrm{i}}$. The "lure of the sea" (Corbin 1994) is only getting stronger and it happens everywhere, giving rise to a booming recreational industry. $\mathrm{Nu}$ merous coastal communities reside on and around the shores of the North Sea, and are where people have lived for ages, drawing their livelihoods from the exploitation of marine resources such as fish. It is to these communities one would go to experience our common cultural marine heritage. People in these communities have their own interests to defend, and they may therefore regard the new developments happening along the coast as a threat. They do not, for instance, always like the new wind farms distorting their sunset view of the horizon.

\section{Wind farms}

The move towards a greener economy based on renewable energy has its own spatial demands. Wind parks at sea are now being introduced at an increasing tempo in all countries surrounding the North Sea. The Directive on Renewable Energy of 2009 established a binding target to supply 20 percent of the total EU energy consumption from green energy by the same year. Thus offshore wind parks in the North Sea have the potential to meet a large share of Europe's energy demand. With consistent wind conditions at sea and the fact that the North Sea is pretty shallow, the costs would be relatively low (Schillings et al. 2012). Wind parks are also discussed in the context of economic development. For the United Kingdom, for instance, the estimate is that they will create 30000 jobs by $2020^{j}$.

Despite promise of a greener energy source, wind parks raise important concerns. One of these concerns pertains to the safety (Jay 2012). Due to their porosity, wind farms are also more dangerous to pass by than oilrigs. Fishing or recreational vessels that trespass these farms may suddenly appear from among the turbines. In bad weather they are not easily spotted, as they may be difficult to distinguish on the radar.

\section{MSP from a fisheries perspective}

Pioneered by European countries, most of which are currently implementing it in one way or another, MSP offers an approach to better marine governance, also within a fisheries context as it builds on the ecosystem perspective now central to fisheries governance. MSP is as challenging within and between sectors domestically as it is at regional scales ${ }^{\mathrm{k}}$. Accordingly, North Sea MSP and fisheries governance retain both a vertical and horizontal dimension. Although MSP in the North Sea brings forward many challenges, there are obviously lessons to be learned that have wider implications. The same is true for fisheries governance in the context of MSP.

When areas of common usage are congested, frictions between different user-groups are bound to occur. It should therefore come as no surprise that competition for marine space is often described by invoking the language of war. Different groups are exploiting different resources and, accordingly, have different spatial needs that are 
often incompatible. However, peaceful co-existence is often possible. For instance, the Dutch MSP approach has been undergoing revision (IDON 2011) towards multiple uses of the same area. In the North Sea, exclusion through zoning is now primarily seen as a MSP measure of the last resort, after the multiple use option is exhausted. However, the cumulative effect of multiple uses on the environment remains a central concern. Resource depletion, pollution, habitat loss, biodiversity decline have increasingly become pressing issues. Protection of marine areas that are vulnerable to human interference is still a relevant measure in many instances.

Essentially, ocean space is not a tabula rasa absent of pre-existing norms, rights and regulations, and "Mare Liberum" does not guarantee full freedom. The usage of marine space and fisheries resources is already heavily influenced by management interventions. Thus, when stakeholders negotiate on how to divide or share space, they do not start from scratch and negotiate outside context. They are ready to defend their interests with all the powers they can muster, including the existing institutional mechanisms if they work to their favor.

Marine legislation and management traditionally follow a sectoral approach, such as for fisheries specifically. They are not designed to fit the whole system, nor do they always facilitate cross-sector interactions. As a consequence, when aggregated to a regional level, i.e. the North Sea, the entire governance system may be less than optimal and prone to create conflict. With such fragmentation, fishers being a weaker party relative to other stakeholders may easily be unable to influence the process and protect themselves from being pushed aside. MSP is no guarantee of a fair and just process unless it is able to break this pattern and create avenues for a more holistic and equitable approach.

For instance, with the "spatial turn" (St. Martin and Hall-Arbor 2008) in marine governance, fishers find themselves in situations where they need to negotiate spatial claims with other user-groups, many of whom only recently arrived in their traditional area. Sometimes fishers are forced to yield, simply because they do not have the clout they need to set the stage. In other case, diplomacy may work. Interestingly, fishers from Urk, a community in the Netherlands, who were cited by Toonen and Mol (2013: 298), expressed:

"Of course, closing fishing grounds is hurtful. We are fishermen! For generations, our family has been fishing at the North Sea. But today's world is different, fishermen are no longer kings in a sole domain. We have to deal with all kinds of other marine activities demanding space. And we have to face that eNGOs, consumers and the whole public is watching us. Collaboration and finding compromises are the only way forward."

Here, Urk fishers realize that they have much to gain by engaging constructively in the process together with other stakeholders. It is this sense of diplomacy that the MSP probably requires. Even if, as Degnbol and Wilson (2008) argue, MSP is a new approach, one that is essential if institutions for ecosystem-based marine and fisheries management is to be established, fishers are likely to be hesitant if not vociferously antagonistic. They would put MSP in a larger context and see it as another step towards enclosure of the fishery commons. As stated in a pamphlet (Fishing on a Square Inch) 
produced by the Dutch Product Board: "If developments continue at this rate, and everything points that way, our fishermen will have only a tiny fraction of the sea left at their disposal" (cf. Degnbol and Wilson 2008; 196-7).

However, there is also room for ambivalence. MSP involves risks but may also provide opportunities to reduce vulnerability. MSP can help to protect fishers against the intrusion of other user-groups. MSP is legitimized by the ecosystem approach to natural resource governance (Gilliland and Laffoley 2008; Douvere 2008), which is what fisheries also need. This approach makes scientists stakeholders in the cause (Knol 2010; Degnbol 2012; van Haastrecht and Toonen 2011), but also a potential ally. How much weight science will carry in the process is, however, an open question. Negotiating conflicting spatial claims is a political game where power counts and where other interests may have more influence than fishers and scientists at the end of the day. MSP is also a political issue, as Kidd and Ellis (2012:62) argue: "There is clearly a politics of MSP at local, national and international scales, which is currently largely hidden."

\section{Use of maps as tool in conflict resolution}

As Toonen and Mol (2013) illustrate in their article about the Dutch North Sea plaice fishery, being able to table good maps is crucial in many cases. Stakeholders who are unable to do so are more likely to be pushed aside by those who can and are more powerful. If fishers cannot provide a credible map that exemplifies their fishing grounds and spatial needs, they are more likely to be displaced when, for instance, a location for wind parks is being researched (Smith and Brennan 2012). A problem for fishers is that their geographical focus is less static than the focus of most other users. This also explains some of their resistance toward mapping in MSP. They fear that their much needed mobility will be reduced as they might become bound by their own maps. In the same way that maps might fence other user-groups out, they may also fence user groups such as fishers in. Thus a map is not just neutral representation of land-or seascape features and uses. They have economic, social and political consequences that raise issue of social justice. As observed by Nietschmann (1997): "Maps are power. Either you will map or you will be mapped."

The role of mapping in MSP is in itself a research issue (Hersoug and Johnson 2012; Knol 2011; Smith and Brennan 2012). New geo-technology, such as GIS (Geographical Information Systems) that affords users the ability to merge and analyze different datasets that exist within different sectors, is an important facilitator of MSP. In fact, such new geo-technologies make MSP both possible and desirable. However, it is important to recall that maps can be biased; some things are highlighted while others are left out. Based on experiences on the east coast fisheries of the US, St. Martin and Hall-Arber (2008: 779) talk about "the missing layer" in marine mapping using GIS. In particular, they refer to an absent social and human dimension:

"Neither the complexity of human communities nor their relationships to locations and resources at sea are represented in current data collection initiatives despite the insistence that marine ecosystems (and ecosystem-based science and management) include human processes, impacts, knowledge, and needs." 
It rests upon the government, as the representative of the common interest, to ensure that the maps are equally empowering to all stakeholders and that inherent biases are minimized. This would require a more systematic effort in generating economic and socio-cultural data about the missing layer. That may however not be as easy as one would think. As Degnbol and Wilson (2008) observe, in the case of the North Sea RAC, fishers often reluctantly provide the requisite information about their fishing practices and spatial movements. Yet, fishers can hardly have it both ways: like it or not, fishers have no other option than to be proactive in MSP. As a fisheries industry representative quoted by Degnbol and Wilson (same page) explains: "It is better to be on the train than being hit by it."

\section{The subsidiarity principle and the issue of scale}

As spatial conflicts are about interests, norms and values, they do not dissipate easily. More scientific knowledge about the SES does not necessarily help. Conversely, it tends to influence the balance of power, as in the case of the MPA initiative in Belgium where "the authorities used scientific knowledge as an argument of power" (Bogaert et al. 2009:881). For this reason, MSP must facilitate a governance process that is interactive and involves stakeholders in the planning process (Kooiman et al. 2005; Ritchie and Ellis 2010; Pomeroy and Douvere 2008; Gopnik et al. 2012). This is not to say that government does not have an important role to play. In fact, certain actions, like legislation, can only be taken by the government. Moreover, spatial conflicts that cannot be resolved by stakeholders require a higher level of authority for appeal.

The "subsidiarity principle" (van Kersbergen and Verbeek 2004) is also relevant to MSP governance, as stressed by the EU Commission in 2008 in a road map for MSP (EU 2008). Subsidiarity is a guiding principle in the Dutch Water Management Plan: "Decentralized whenever possible, centralized whenever needed". The same cannot apparently be said of the CFP, which Degnbol and Wilson (2008:189) characterize as "perhaps the most top-down fisheries management system on the planet." The challenge is to find agreement on what is "possible" and when things are "needed". Neither the higher nor the lower level can be expected to easily let their power go. What appears to be impossible, however, can sometimes be made possible, for instance through institutional innovation. Thus, the formation of the RACs for fisheries management has provided opportunities for decentralization and stakeholder involvement, including the fishing industry, that did not exist before. Subsidiarity is therefore also about creating opportunities (Kooiman 2003), which in turn is fundamentally about governability-i.e. the capacity to govern (Kooiman 2008)-a facet that can be enhanced through MSP given its particular institutional designs that because of the multi-scalar issues involved requires governance mechanisms that for the North Sea cut across national borders and sector boundaries.

Today, MSP is mostly carried out at the national level, which leaves issues at local and supra-national levels in an untouched void. MSP also needs to happen at the level of the local community to avoid conflict and to ensure that stakeholders are involved in the process. MSP cannot just deal with issues that are broad; it also must pay attention to detail specific to a particular place. Henry Mintzberg suggests a governance principle that would also apply to MSP; "the more complex the environment, the more 
decentralized the structure (Mintzberg 1983: 138). This has also been applied for the co-management of fisheries (Jentoft 2007). The reason for this is further elaborated by Pressman and Wildavsky (1984: 205), who argue that "the closer one is to the source of the problem, the greater is one's ability to influence it, and the problem solving ability to complex systems depends not on the hierarchical control but on maximizing discretion at the point where the problem is most immediate."

Depending on what the problem is, this may call for decentralization of decisionmaking authority. In some instances the problem is mostly felt at higher scales at which the decision-making capacity may be low. Such is the case when several countries share a management problem and there is no institution that binds them together and facilitates collective action. Marine ecosystems are not always aligned with national boundaries, and fish stocks pass from one country's EEZ to another. Therefore there is a need for both MSP and fisheries governance at a regional scale. With the establishment of the RACs, there may be opportunities for decentralization of fisheries management functions that are not currently put to use, Lack of institutions such as RACs may make fisheries ineffective and therefore vulnerable to MSP initiatives, given the anticipated play of power that such a planning initiative may invite to.

Coordination and cooperation at regional scales is supported by the Marine Strategy Framework Directive (adopted in June 2008), which aims at improving the environmental status of Europe's seas. Dogger Bank is a case in point. Countries evaluated (Germany, Belgium and the Netherlands) by the MASPNOSE project do not readily share information with each other, and not all are equally accommodating to stakeholder involvement ${ }^{1}$. According to this project's findings, the Netherlands seems to be more prepared to do so than Belgium and Germany, perhaps a testament to the culture of the Polder model that again has influence here, but efforts on behalf of all the involved countries are essential.

\section{Concluding remarks}

With a congested North Sea and the developments that can be seen on the horizon, the stakes are high, not at least for those whose livelihoods depend on the harvest and use of natural resources such as fish. The North Sea needs to improve its environmental status and the health of its fish stocks as some of experiencing major difficulties due to overfishing and environmental degradation. From this perspective, MSP and its ecosystem-based approach seems to be "an idea whose time has come" (Gilliland and Laffoley 2008: 787). It may not be the only answer to these challenges, but is likely to an essential part of it.

Still there is a need to be cautious. MSP may not appear to be a win-win. On the contrary, for the least powerful stakeholders, those who are poorly represented and who have few resources to back up their claims, they risk being ignored in the planning process. For them MSP may add further pressure and result in a loss. As illustrated in this paper, there is reason to assume that fishers and their communities may be within this group of stakeholders. MSP is a governance mechanism that may provide a more secure tenure but it also involves the risk of losing it, for instance as a result of spatial mapping. They have therefore reason to be ambivalent regarding this new tool and how it works from a fisheries governance perspective. 
Leaving stakeholders to fight for space on their own is a recipe for social and ecological failure. It would also have implications regarding social justice as some user-groups do not only have more urgent needs and stakes than others, but their powers to protect their interests, define the problems, and shape the planning process are not equally distributed. Fisheries have large stakes but relative to other users such as the oil or shipping industry, they are a small player risking to be displaced. Therefore, spatial ordering through zoning is necessary also as a protective measure, but territorial boundaries cannot always be impenetrable, especially for fishers who need to remain mobile.

Yet, as Douvere (2008) has argued, MSP cannot just be about zoning, it must also be about negotiating interactions among user groups within complex SESs that are highly diverse, multi-scalar and dynamic, and with targets that are mobile and fluid due to natural as well social characteristics. This is what makes the marine environment different from its terrestrial counterpart. In dealing with dynamic systems that are complex, diverse and multiscalar, governance systems must assume similar traits to be up to the task (Duck 2012; Kidd and Ellis 2012, Kooiman et al. 2005). MSP is no exception from this rule.

As far as the North Sea is concerned, with the institutional and cooperative frameworks backing up governance at both the national and EU levels and for particular sectors such as fisheries, there is reason to believe that MSP has a greater chance of succeeding here than in many other regions of the world. Still, the need for improved coordination of MSP efforts at all scales and across sectors remains a priority for the North Sea. The social and economic dimensions need attention, and stakeholder participation must be facilitated and playing fields levelled not only in the interest of justice and democracy, which are important principles in themselves.

As Mintzberg (1983) and Pressman and Wildavsky (1984) observe, this is also fundamentally about effective governance and the need to situate decision-making authority at most appropriate level. Some issues must certainly be dealt with at higher scales, such as for the North Sea as a whole, but not every issue can be handled from far away. This is now recognized within the EU, where the subsidiarity principle is adopted albeit not systematically-and certainly not at the local level as compared with the national level (van Kersbergen and Verbeek 2004).

These elements in turn require novel institutional designs, somewhat along the lines of the Regional Advisory Council system in fisheries and the Polder model originally for water management and an emphasis on the criteria of "good governance" across the board. Neither of these institutions is perfect, as no governance system is, but they do build on sound and well-proven governance principles that continue to be relevant and effective and have broad application. It is these principles, the values and norms that underpin them and the concrete organizational solutions they have led to, that are worth considering in MSP and fisheries governance for the North Sea, for other marine regions in Europe, and elsewhere.

\section{Endnotes}

${ }^{a}$ http://www.birdlife.org/eubiodiversityreport2012/?page_id=1888.

${ }^{\mathrm{b}}$ www.scotlink.org/files/policy/ParliamentaryBriefings/LINKfilenoteMPA1Oct2011.pdf.

${ }^{\mathrm{c} E x a c t}$ comparison is difficult as fishing vessels in the Netherlands are registered by their engine horsepower. In 2009 there were 308 cutters, 14 trawlers, and 193 miscellaneous. A 
third of the cutters are between 24-60 meters. Others are smaller but most of them larger than 10 meters presumably.

${ }^{d}$ http://www.compendiumvoordeleefomgeving.nl/indicatoren/nl1538-Viskweek.html? $\mathrm{i}=20-110$.

ehttp://webfd.fd.dk/stat/Akvakultur_tab/prod_art_12_eng.html.

${ }^{f}$ For example, in 2007, there were 143 oil and gas platforms in the Dutch part of the North Sea. These include drilling rigs, service platforms and platforms that are no longer in use, but have not been dismantled yet. Around 130 production locations are in use, of which the major part is related to gas winning. Most of the platforms are located in the central part of the Dutch Continental Shelf. (www.noordzeeloket.nl).

ghttp://www.statoil.com/no/EnvironmentSociety/Environment/impactassessments/ fielddevelopments/Downloads/Utbygging\%20av\%20Valemon\%20-\%20Konsekvenser\% 20for\%20fiskeri.pdf.

hwww.noordzeeloket.nl.

${ }^{i}$ http://www.government.nl/issues/water-management/water-quality/towards-betterwater-quality.

${ }^{j}$ https://www.gov.uk/government/news/multi-million-pound-investment-in-offshorewind-industry-to-unlock-billions-in-uk-economy.

${ }^{\mathrm{k}}$ In this paper, we talk about marine spatial planning instead of maritime spatial planning (as used by the European Commission.) Despite slightly different emphases, both concepts center around the spatial regulation of human activities in a complex and dynamic marine environment. We use marine spatial planning, which is most widely used in the scholarly debate."

${ }^{\mathrm{I}}$ The multi-national MASPNOSE project is looking at the entire North Sea and funded by the DG MARE, including the Dogger Bank issue. http://www.wageningenur.nl/en/show/ Maspnose-Maritime-spatial-planning-in-the-North-Sea.htm. http://eu.fotolia.com/search?k= wind+farms\&filters\%5Bcontent_type\%3Aall\%5D=1.

Competing interests

The authors declare that they have no competing interests.

\section{Authors' contributions}

Both authors carried out research for this paper and contributed with written text. SJ had the responsibility for the overall structure. Both authors read and approved the final manuscript.

\section{Acknowledgements}

This paper was first prepared for the symposium "The North Sea; the Past, the Present and the Future", held at the Royal Palace in Amsterdam on November 2, 2012. We are grateful for constructive comments by Maria Victoria Solstrand, Glen Smith, and two anonymous reviewers.

Received: 26 March 2013 Accepted: 4 September 2013

Published: 8 January 2014

\section{References}

Agardy, T, GN Di Sciara, and P Christie. 2011. Mind the gap: addressing the shortcomings of marine protected areas through large scale marina spatial planning. Marine Policy 35: 326-232.

Bogaert, D, A Cliquet, and F Maes. 2009. Designation of marine protected areas in Belgium: a legal and ecological success? Marine Policy 33: 878-886.

Cardwell, E. 2012. Invisible fishermen: the rise and fall of the British small boat fleet. In European fisheries at a tippingpoint, ed. P Højrup and K Schriewer, 367-411. Murcia: Universidad de Murcia.

Chuenpagdee, R, J Pascual-Fernandéz, E Szelianszky, JL Alegret, J Fraga, and S Jentoft. 2013. Marine protected areas: rethinking their inception. Marine Policy 39: 234-240.

Corbin, A. 1994. The lure of the sea: the discovery of the seaside in the western world, 1750-1840. Univ of California Press.

Degnbol, D. 2012. Slightly covered all the time: the science of sandbanks on the Dogger Bank. PhD thesis. Aalborg University: Department of Development and Planning.

Degnbol, D, and DC Wilson. 2008. Spatial planning on the North Sea: a case of cross-scale linkages. Marine Policy 32: 189-200. 
Douvere, F. 2008. The importance of marine spatial planning in advancing ecosystem-based sea use management. Marine Policy 32(5): 762-771.

Douvere, F, and C Ehler. 2008. Introduction. Marine Policy 32: 759-761.

Douvere, F, and C Ehler. 2009. New perspectives on sea use management: initial findings from European experience with marine spatial planning. Journal of Environmental Management 90: 77-78.

Drankier, P. 2012. Embedding maritime spatial planning in national legal frameworks. Journal of Environmental Policy and Planning 14(1): 7-27.

Duck, RW. 2012. Marine spatial planning: managing a dynamic environment. Journal of Environmental Policy and Planning 14(1): 67-79.

EU. 2008. Roadmap for Maritime Spatial Planning: Achieving common principles in the EU. Brussels: Commission of the European Communities.

Fock, HO. 2011. Natura 2000 and the European common fisheries policy. Marine Policy 35: 181-188.

Gilliland, PM, and D Laffoley. 2008. Key elements and steps in the process of developing ecosystem-based marine spatial planning. Marine Policy 32: 787-796.

Glasbergen, P. 2002. The green Polder model: institutionalizing multi-stakeholder processes in strategic environmental decision-making. European Environment 12: 303-315.

Gopnik, M, C Fieseler, L Cantral, and K McClellan. 2012. Coming to the table: early stakeholder engagement in marine spatial planning. Marine Policy 36: 1139-1149.

Halpern, BS, S Walbridge, KA Selkoe, CV Kappel, F Michelli, JF D'Agrosa, KS Bruno, C Casey, HE Ebert, R Fox, D Fujita, HS Heinemann, EMP Lenihan, MT Madin, ER Perry, M Selig, RS Spalding, and R Watson. 2008. A global map of human impact on marine ecosystems. Science 319: 948-952.

Hersoug, B, and JP Johnson (eds.). 2012. Kampen om plass på kysten: interesser og utviklingstrekk i kystsoneplanleggingen. Oslo: Universitetsforlaget.

ICES. 2011. Report of the ICES Advisory Committee: Book 6. Copenhagen: North Sea.

IDON. 2011. Integrated Management Plan for the North Sea 2015 (Revision). Rijswijk, the Netherlands: Interdepartmental Directors' Consultative Committee North Sea (Interdepartementaal Directeurenoverleg Noordzee-IDON).

Jay, S. 2012a. Marine space: manoeuvring towards a relational understanding. Journal of Environmental Policy and Planning 14(1): 81-96.

Jay, S, G Ellis, and S Kidd. 2012b. Marine spatial planning: a new frontier? Journal of Environmental Policy and Planning 14(1): $1-5$.

Jay, S, W Flannery, J Vince, W-H Liu, J Guifang Xue, M Matczak, J Zaucha, H Janssen, J Van Tatenhove, H Toonen, A Morf, E Olsen, JL Suárez de Vivero, JC Rodríguez Mateos, H Calado, J Duff, and H Dean. 2012c. Coastal and Marine Spatial Planning: International Progress in Marine Spatial Planning. In Ocean Yearbook 27, 171-212.

Jentoft, S. 2007. Limits of governability? Institutional implications for fisheries and coastal governance. Marine Policy 31: 360-370.

Jentoft, S, and R Chuenpagdee. 2009. Fisheries and coastal governance as a wicked problem. Marine Policy 33: 553-560.

Jentoft, S, T Van Son, and M Bjørkan. 2007. Marine protected areas: a governance system analysis. Human Ecology 35: 611-622.

Kidd, S, and G Ellis. 2012. From the land to the sea and back again? Using terrestrial planning to understand the process of marine spatial planning. Journal of Environmental Policy and Planning 14(1): 49-66.

Kidd, S, and D Shaw. 2013. Reconceptualising territoriality and spatial planning: insights from the sea. Planning Theory \& Practice. 14(2): 180-197.

Kidd, S, A Plater, and C Fried (eds.). 2011. The ecosystem approach to marine planning and management. London: Earthscan.

Kjær, AM. 2004. Governance. Cambridge: Polity Press.

Knol, M. 2010. Scientific advice in integrated ocean management: the process towards the Barents Sea plan. Marine Policy 34(2): 252-260.

Knol, M. 2011. Mapping ocean governance: from ecological values to policy instrumentation. Journal of environmental management and planning 54(7): 979-995.

Kooiman, J. 2003. Governing and governance. London: Sage Publication.

Kooiman, J. 2008. Exploring the concept of governability. Journal of Comparative policy analysis 10(2): 171-190.

Kooiman, J, M Bavinck, S Jentoft, and R Pullin (eds.). 2005. Fish for life: interactive governance for fisheries. Amsterdam: Amsterdam University Press.

Mintzberg, H. 1983. Structures in fives: designing effective organizations. Englewoods Cliffs: Prentice-Hall International, Inc.

Nietschmann, BQ. 1997. "The Making of the Maya Atlas". In Maya Atlas, 136-149. Berkeley, CA: North Atlantic Books.

Ounanian, K, A Delaney, J Raakjær, and P Ramirez-Monsalve. 2012. On equal footing: stakeholder perspectives on the marine strategy framework directive as a mechanism of the ecosystem-based approach to marine management. Marine Policy 36: 658-666.

Pomeroy, R, and F Douvere. 2008. The engagement of stakeholders in the marine spatial planning process. Marine Policy 32(5): 816-822.

Pressman, JL, and A Wildavsky. 1984. Implementation. Berkeley: University of California Press.

Ritchie, H, and G Ellis. 2010. A system that works for the sea? Exploring stakeholder engagement in marine spatial planning. Journal of Environmental Planning and Management 53(6): 701-723.

Rittel, H, and M Webber. 1973. Dilemmas in a general theory of planning. Policy Sciences 4: 155-169.

Schillings, C, T Wanderer, L Cameron, JT van der Wal, J Jacquemin, and K Veum. 2012. A decision support system for assessing offshore wind energy potential in the North Sea. Energy Policy 49: 541-551.

Schreuder, Y. 2001. The Polder model in Dutch economic and environmental planning. Bulletin of Science, Technology \& Society 21(4): $237-245$

Scottish Government. 2011. Scotland's National Marine Plan-Pre-Consultation Draft.. Available from: http://www. scotland.gov.uk/Publications/2011/03/21114728/0

Smith, G, and R Brennan. 2012. Losing our way with mapping: thinking critically about marine spatial planning in Scotland. Ocean and Coastal Management 69: 210-216. 
St. Martin, K, and M Hall-Arber. 2008. The missing layer: geo-technologies, communities, and implications for marine spatial planning. Marine Policy 32: 779-786.

Toonen, H, and AP Mol. 2013. Putting sustainable fisheries on the map? Establishing no-take zones for North-Sea plaice fisheries through MSC certification. Marine Policy 37: 294-304.

Van Ginkel, R. 2009. Braving troubled waters: sea change in a Dutch fishing community. Amsterdam: Amsterdam University Press.

Van Haastrecht, EK, and HM Toonen. 2011. Science-policy interactions in MPA site selection in the Dutch part of the North Sea. Environmental Management 47(4): 656-670.

Van Hoof, L, and J Van Tatenhove. 2009. EU marine policy on the move: the tension between fisheries and maritime policy. Marine Policy 33: 726-733

Van Kersbergen, $K$, and B Verbeek. 2004. Subsidiarity as a principle of governance in the European Union. Comparative European Politics 2: 142-162.

Van Leeuwen, J, and J Van Tatenhove. 2010. The triangle of marine governance in the environment governance of Dutch offshore platforms. Marine Policy 34: 590-597.

Woldendorp, J, and H Keman. 2007. The Polder model reviewed: Dutch corporatism 1965-2000. Economic and Industrial Democracy 28(3): 317-347.

Yergin, D. 1991. The prize: the epic quest for oil, money, and power. New York: Simon \& Schuster.

Zacharoula, K, F Maes, M Rabaut, M Vincx, and S Degraer. 2013. The integration of nature conservation into the marine spatial planning process. Marine Policy 38: 133-139.

doi:10.1186/2212-9790-12-13

Cite this article as: Jentoft and Knol: Marine spatial planning: risk or opportunity for fisheries in the North Sea? Maritime Studies 2014 12:13.

Submit your manuscript to a SpringerOpen ${ }^{\circ}$ journal and benefit from:

- Convenient online submission

Rigorous peer review

- Immediate publication on acceptance

- Open access: articles freely available online

- High visibility within the field

Retaining the copyright to your article

Submit your next manuscript at $>$ springeropen.com 